Article

\title{
The Nordic Council of Ministers: Aspirations for More Political Relevance
}

\author{
Tobias Etzold
}

Department of Historical and Classical Studies, Norwegian University of Science and Technology, 7491 Trondheim, Norway; E-Mail: tobias.etzold@ntnu.no

Submitted: 19 June 2020 | Accepted: 28 August 2020 | Published: 3 November 2020

\begin{abstract}
Due to changing circumstances and new challenges, the Nordic Council of Ministers underwent an incremental process of change and some modest transformation since the 1990s. However, there has never been a major overhaul of structures and contents owing to considerable inertia. The most recent modernisation process, aiming at more political relevance and flexibility, has been ambitious but whether it has been a success remains unclear thus far. Weaknesses and limits in cooperation in the Nordic Council of Ministers are obvious, i.e., no majority voting or 'opting-out' system, a lack in supra-national structures and policies and no common immigration, foreign, security and EU policies. Nonetheless, the organisation has at least some relevance and meaning for the Nordic countries and the potential to promote and facilitate cooperation in policy areas in which common interests exist, such as environment, climate, research and social affairs. Therefore, rather than constituting a common political order of its own, Nordic cooperation, as it is conducted within the Nordic Council of Ministers, is best characterized by differentiated integration, promoting full integration only to a limited extent but respecting integration to different extents and speeds by fostering cooperation and coordination of certain policies where possible and desired.
\end{abstract}

\section{Keywords}

modernization; Nordic cooperation; Nordic Council of Ministers; political reform; political relevance

\section{Issue}

This article is part of the issue "Rediscovering Nordic Cooperation" edited by Anne Elizabeth Stie (University of Agder, Norway) and Jarle Trondal (University of Agder, Norway/ARENA University of Oslo, Norway).

(C) 2020 by the author; licensee Cogitatio (Lisbon, Portugal). This article is licensed under a Creative Commons Attribution 4.0 International License (CC BY).

\section{Introduction}

Since their inauguration, the main institutions of Nordic cooperation-the intergovernmental Nordic Council of Ministers and the inter-parliamentary Nordic Councilhave persistently had to react to new challenges and external changes. This meant adapting to new circumstances in order to maintain or, in the optimum case, to increase their political relevance and impact. This was highlighted in the period after the end of the Cold War and around the EU accession of Sweden and Finland in 1995 and to a lesser extent after the EU wider enlargement in 2004. In response to new circumstances and major internal and external challenges-for example East-West tensions, security, migration, Brexit and the crisis of the welfare state-a new ambitious reform process in the Nordic Council of Ministers was launched in 2014. Addressing intra-Nordic cooperation, the most important ambitions entailed a more political approach to cooperation, the inclusion of new policy areas, more flexible institutional structures and various new structures. Considering the increasingly more important external dimension of Nordic cooperation, undertaking new steps towards a closer Nordic EU cooperation and greater internationalization were also part of the ambition.

However, it still has to be examined whether and, if so, to what extent, the most recent reforms and related institutional changes have been effective and have contributed to making the Nordic Council of Ministers stronger, more influential, politically relevant and flexible. Several indicators speak for this, others do not as will be elaborated in this article. The Nordic Council of Ministers still lacks any supranational elements and 
competences in key areas of politics (i.e., foreign affairs, security and immigration). Furthermore, a real common Nordic EU-policy in which the Nordic Council of Ministers would play a significant role still does not exist.

The article first provides a brief overview of the Nordic Council of Minister's development, functions, structures and relevance within the wider context of Nordic cooperation as well as an account of changes and institutional reforms within the Nordic Council of Ministers since the 1990s. The article's main objectives are to take stock and to examine the most recent changes in the structures and working modes of the Nordic Council of Ministers since 2014 and their implications for the organisation's political relevance and impact. For this purpose, a thorough content analysis of policy documents by the Nordic Council of Ministers and national governments as well as academic literature has been conducted. Relevant statements and indications for and/or against the organisation's adaptability and political relevance have been derived from these texts and analysed. While paying attention primarily to the Nordic Council of Ministers, occasional references to the Nordic Council are also made where appropriate and relevant for the analysis since both organisations are closely interlinked. Reform efforts in one body often have repercussions for the other.

\section{The Nordic Council of Ministers: Development, Functions and Structures}

Nordic cooperation was institutionalized over the course of several decades. While cooperation has taken place before on a loose basis, the inter-parliamentary Nordic Council was established in 1952 as a first important step in efforts to shape a permanent institutional foundation. However, the body came into existence without any international treaty basis. Its inauguration was only endorsed by the national parliaments (Laursen \& Olesen, 1998, p. 24). Only when the 'Nordic Cooperation Treaty'/'Helsinki agreement' was signed in 1962, was Nordic cooperation provided with at least some sort of legal framework. The Treaty's adoption was "a milestone in Nordic cooperation" (Wendt, 1981, p. 39). Despite its general and non-obligatory character, the Treaty clarified what Nordic cooperation should incorporate as well as its main objectives. When the Nordic Council of Ministers was established and the external pre-conditions for the cooperation changed, it was subsequently amended in 1971 and 1993.

In its first 20 years of existence, the Nordic Council not only served as a forum for cooperation among the parliaments but also among the Nordic countries' governments. The governments' representatives had, however, no voting rights in the decision-making process (Wendt, 1965, p. 12) and most of its activities took place at the parliamentary level. Nordic governmental cooperation activities were sidelined, weak and uncoordinated (Nordiska Rådet, 1973, p. 26). After failing to imple- ment new steps of Nordic integration, i.e., the institutionalized Nordic Economic Community, the Nordic Council of Ministers was established in 1971 as a separate intergovernmental institution. Its main tasks were to strengthen ties and to promote more regular and structured cooperation and coordination among the governments. As a consequence, the Nordic Council's role changed as it then turned into a purely inter-parliamentary organisation. It then became one of the Nordic Council's main functions to monitor intergovernmental cooperation and to develop and maintain a good and close dialogue with the Nordic Council of Ministers (Jutila \& Tikkala, 2009, p. 6). The close links between the parliamentary level and the governments and the Nordic Council of Ministers are an essential part of Nordic cooperation. In more recent years, it has become common practice that government representatives, even prime ministers, address the annual Nordic Council meetings and discuss issues of importance with the members of parliaments. This link is a special feature of Nordic cooperation, distinguishing it from other forms of international cooperation where the governmental and parliamentary levels are more strictly divided (Hagemann, 2005 , p. 3). Since then, the main tasks of the Nordic Council were to issue recommendations to the governments, take initiatives, give inspiration, exert control and express criticism (Wendt, 1965, p. 21).

The Nordic Council of Ministers is responsible for the implementation of common policies and projects within a contractually regulated system of rules. It promotes and coordinates the cooperation among the Nordic countries' governments in a wide range of policy areas and fields of public administration. However, as a general rule it has been established that Nordic cooperation "never goes further than the interests of each country permit" (Nordiska Rådet, 1973, p. 27). The Nordic Council of Ministers' core activities include social affairs and the development of the Nordic welfare state model, environment, culture as well as research and education. The cooperation on cultural issues, education and research is central as these topics form important elements of Nordic identity in terms of language, culture and values (Nordisk Ministerråd, 1998, p. 2). This also shows that Nordic cooperation is not just about states' interests; it can be best described as a hybrid of calculated interest-based and identity-based partnerships (Olsen, 1998, p. 363). It is also within the aforementioned areas as well as energy, consumer protection, technology and regional development in which the Nordic Council of Ministers developed fairly advanced capabilities for problem solving (Schumacher, 2000a, p. 15). In policy areas in which common interests do not prevail, there is no (or very limited) formal and institutionalised cooperation. Traditional foreign policy, (military) security and defence policy were excluded from formal cooperation, as was closer economic cooperation. The security policy traditions, multilateral ties and economic orientations of the Nordic countries differed too considerably 
in order to render fruitful cooperation on a permanent basis possible.

Officially, the Nordic countries' prime ministers head intergovernmental Nordic cooperation as formalized in the Nordic Council of Ministers. The prime ministers meet for informal consultations at least twice a year. Currently, the organisation consists of eleven ministerial councils. The Ministerial Council for general Nordic cooperation, consisting of the ministers for Nordic cooperation, coordinates, similarly to the Council of General Affairs of the EU, the formal cooperation. The other ten councils are responsible for one specific or several policy areas: labour, sustainable growth, fisheries, aquaculture, agriculture, food and forestry, gender equality, culture, legislative affairs, environment and climate, health and social affairs, education and research, and finance. Since 2016, there is also an ad hoc Council for digitalization. Decisions in any of the ministerial councils are taken by unanimity. The Nordic Council of Ministers is chaired by a one-year presidency that rotates among the five member states. The presidency drafts a programme with priorities, objectives and guidelines for the upcoming year. While the ministers only meet occasionally to take the political decisions, the Nordic Committee for Cooperation, consisting of high-level officials from the Nordic countries' ministries of foreign affairs, is responsible for the day-to-day coordination of general cooperation and the more technical decision-making process. Various expert committees of national senior officials from the various line ministries prepare the decisionmaking process and the implementation of activities in the specific issue areas, supporting the work of respective ministerial council. The Nordic Council of Ministers Secretariat in Copenhagen is an important backbone for the institutionalized intergovernmental cooperation. Its tasks are to initiate, implement and follow up on policy decisions; to develop knowledge on which to base Nordic solutions, and to build networks for the exchange of experiences and ideas (Nordic Council of Ministers, 2020). The Secretariat is headed by a secretary-general, usually a senior politician from of one the five member states, who is responsible for the day-to-day running of the organisation. The Secretariat employs about 100 people divided into three thematic departments, i.e., culture and resources, growth and climate, and knowledge and welfare, the Secretary-General's office in charge of cross-cutting issues and international affairs, as well as two supporting departments, namely human resources, administration and law, and public relations. The Nordic Council of Ministers runs regional information offices in the capitals of the three Baltic States, Estonia, Latvia and Lithuania, and used to have offices in St. Petersburg and Kaliningrad for several years. A wide network of several institutions, centres and offices work under the auspices of the Nordic Council of Ministers including, for example, Nordforsk fostering Nordic research cooperation, Nordic Energy Research, the Nordic Innovation Centre and various cultural institutions.

\section{Changes and Institutional Reforms within the Nordic Council of Ministers}

\subsection{Reform Efforts since the 1990s}

Since they were established, the institutions of Nordic cooperation had to persistently react to newly emerging internal and external challenges and to adapt to new circumstances in order to maintain their relevance. The external conditions and circumstances for Nordic cooperation and its institutions had, in particular, changed fundamentally by the end of the 1980s and early 1990s when the Cold War came to an end and the Soviet Union collapsed. Finland and Sweden joined the EU in 1995, while Norway and Iceland stayed out but joined the newly established European Economic Area, gaining access to the EU's internal market by 1994. Thus, the purpose and the added value of Nordic cooperation needed to be redefined in relation to European integration. However, there were significant doubts about the current and future relevance of institutionalised Nordic cooperation, some negativism, perceiving in particular the Nordic Council of Ministers and the Nordic Council as outdated, and related demands to close these bodies (for example, Bagerstam, 1995, pp. 11-12). Nonetheless, there was a widespread notion that Nordic cooperation and its institutions still had a place within the new international system but simultaneously had to adapt to "the needs of the changing external environment" (Stenbäck, 1997, p. 7) as well as the changes in the member states' national interests and needs.

Both the Nordic Council and the Nordic Council of Ministers adopted a new three-pillar structure for their work, covering intra-Nordic cooperation, cooperation with the Nordic region's ('Norden') adjacent areas (the three Baltic states, the Baltic Sea region, Northwest Russia as well as the Barents and Arctic regions) and Nordic cooperation in a wider European context. To match this, the Nordic Council abandoned its previous committee structure based on particular issue areas (e.g., economy, environment and culture) and instead established three committees along the lines of the three geographically-oriented pillars in 1995. While looking good on paper, in practice the new structure was unclear and did not work well. The three committees had to deal with too many different issues that partly did not connect. The new structure did also not correspond well with the still more topic-oriented the Nordic Council of Ministers (Kristiansen, 2001, p. 57). Because of these shortcomings and after intensive deliberations, the Nordic Council returned to its original committee structure in 2001.

The Nordic Council of Ministers initiated a number of structural changes, such as establishing an annually rotating Council Presidency among the member countries for a smoother coordination of its activities and the aforementioned information offices in the Baltic States and in St. Petersburg. It reduced the number of 
formal committees of senior officials and the number of institutions operating under its umbrella and introduced, where necessary, a new definition of their work (Schumacher, 2000b, p. 214). Furthermore, structures were created to better coordinate the EU policies of the Nordic countries such as a contact group consisting of representatives from the permanent representations of the Nordic countries in Brussels to foster the cooperation between them and to provide the Nordic Council of Ministers with relevant information. In addition, the Nordic Council of Ministers Secretariat jointly with the permanent representations obtained the status of a think-tank on EU-related questions. However, these measures were not effective or helpful in practice (Maertens, 1997, p. 42) and were soon abandoned.

In 1997, the Nordic Council of Ministers launched a 'strategy-project' that had particular impact on organisational and administrative aspects in relation to the new political strategies. This was necessary as the Nordic Council of Ministers' organisational structure was perceived as confusing, inflexible and full of inertia, becoming a stumbling block for developing the cooperation further (Bennedsen, 1998). The project aimed at improvements in the allocation and distribution of responsibilities and competences among the various actors within the system; a re-organisation of the Nordic Council of Ministers Secretariat; a more effective steering of agreements and the budget in the Nordic institutions, and improved control of projects funded from the joint budget. The Secretariat was enabled to obtain a more active role in the preparation and implementation of political decisions in relation to the ministerial councils (Nordisk Ministerråd, 1998, p. 1). The report Open to the Winds of Change: Norden 2000 identified several trends as main challenges and tasks for Nordic cooperation in the 21st century: globalisation, European integration, environment, democracy, welfare, market and economy, culture and education, demographic development and migration, security and technological development (Nordic Council \& Nordic Council of Ministers, 2000). The same report was critical of the large number of ministerial councils (18 at the time) and institutions working under the auspices of the Nordic Council of Ministers with an eye to effectiveness and efficiency. Therefore, a reform in 2005-2006 aimed at reducing the number of ministerial councils from 18 to 11 , partly through mergers, in order to establish a clearer prioritisation and to render Nordic cooperation more effective, focussed, dynamic, forward-looking, concrete and politically as relevant as possible (Hedegaard, 2005, pp. 2,35$)$. In order to match the new political structures and their thematic focus and to shape clearer responsibilities, the Nordic Council of Ministers Secretariat was subsequently reorganised in terms of the four sectoral departments' issue-related competences and responsibilities, as were the budgetary structures and procedures. An evaluation of the 2005 reforms suggested several further measures, for example another restructuring of the secretariat, reducing the number of departments from four to the current three, and establishing guidelines for better cooperation between secretariat and presidencies, clearly outlining the respective responsibilities and tasks, adopted in 2009. The main aim with all these measures was to renew the Nordic Council of Ministers constantly so that it could remain a political institution compatible with the times (Nordisk Ministerråd, 2009, p. 30).

\subsection{Modernisation Process 2014-2017}

This was also the main objective of a new process of modernisation and reform from 2013/2014, addressing new challenges and demands as well as criticisms. Despite earlier efforts to become more flexible, dynamic and demand-oriented, an often heard criticism was that the Nordic Council of Ministers was still too bureaucratic and cumbersome, lacking clear political substance, relevance and leadership (Strang, 2012, p. 66). This process was officially launched when the ministers for Nordic cooperation developed four visions for future cooperation titled Tillsammans är vi starkare ('Together we are stronger') in February 2014 (Nordisk Ministerråd, 2014a). The visions included both inward- and outward-looking ambitions. On the one hand, efforts of traditional Nordic cooperation were to be continued: to strive for a borderless Nordic region, especially in terms of further removing border obstacles to continue allowing free movement for all citizens and companies across Nordic borders, and an innovative Norden with a strong focus on welfare, education and training, creativity, entrepreneurship, sustainability and research. On the other hand, in response to growing international interest in Nordic experiences and solutions, the ambition was to promote the Nordic welfare model as well as the model of Nordic cooperation more strongly outside the region, contributing to a more visible Nordic region. Finally, the vision of an outward-looking Norden underlined the ambition to intensify Nordic cooperation with regard to global affairs as well as within international organizations (Nordisk Ministerråd, 2014a).

Building on these ambitious future visions, the Nordic Council of Ministers initiated a process of modernization and reform aimed at highlighting and strengthening the political relevance of the cooperation, making it more effective and opening up new fields of cooperation (Opitz \& Etzold, 2018, pp. 3-4). Based on the report Nyt Norden ('The New North') with 39 recommendations by then the Nordic Council of Ministers Secretary General Dagfinn Høybråten, the ministers for Nordic cooperation adopted a catalogue of reforms covering four areas in autumn 2014: (i) ministerial cooperation, (ii) an effective the Nordic Council of Ministers Secretariat, (iii) budgeting as well as (iv) the project and programme level (Nordisk Ministerråd, 2014b, pp. 11-12). Among many proposed measures, the meetings of the ministerial councils should acquire a stronger strategic focus on relevant policy issues in their respective fields and their long- 
term implications for Nordic cooperation rather than small-scale administrative issues (Nordisk Ministerråd, 2014b, pp. 26-28). In particular, the need for a more systematic dialogue on international and EU policy issues as a significant field of future cooperation has been identified. Related issues of common interest should be given a more prominent place on the agenda of all ministerial council meetings (Nordisk Ministerråd, 2014b, p. 4). The recommended changes specifically upgraded the role of the Secretariat as well as the position of the Secretary-General and his right to take initiatives as engines of the cooperation. The latter was granted explicit permission to set the Nordic Council of Ministers' procedural rules and meeting agendas (Nordisk Ministerråd, 2014b, pp. 60-61). Furthermore, the budgeting process for the Nordic Council of Ministers institutions should become leaner and more flexible. In addition, it set itself the aim of better linking and evaluating the numerous Nordic Council of Ministers projects and programmes. These and more other specific reform measures started to be implemented soon after, resulting in various changes in the modes of operation.

This, however, was not the end of the story. The ministers for Nordic cooperation soon saw the need to continue and expand the modernization agenda and to do even more to strengthen the relevance of the cooperation for politics, business and civil society. The background to this was the deterioration in relations with Russia following the crisis in Ukraine, which had an impact on the Nordic Council of Ministers' involvement in northwest Russia as it had to close its offices there which were categorized as foreign agents by Russian authorities. In addition, the considerable migration movements of 2015 that directly affected all five Nordic countries, as well as the EU's legitimacy crisis, increased the pressure to take new action in reaction to these developments and created both new challenges and opportunities for Nordic cooperation. In spring 2016, a new report Nordens tid er nu ('The Nordic Region's time is now') was issued as the basis for further reforms (Nordisk Ministerråd, 2016a). Building on the earlier reform report and the changes already concluded and implemented, it entailed a number of more traditional key issues, such as developing the North into the world's most integrated region, strengthening Nordic commitment to sustainable growth and increasing the dialogue with the citizens (Nordisk Ministerråd, 2016a, p. 10). Thus, the main objectives of the 11 measures subsequently adopted by the ministers were to continue making the cooperation more effective and flexible by creating more dynamic budgeting procedures and working modes in the various committees as well as a smoother interaction between government officials and the ministers (Nordisk Ministerråd, 2016a, pp. 9-13). The structures should be enabled to react more quickly to new developments and demands. These implied in practice the reorganization of several ministerial councils. For example, the council for environment was expand- ed to include climate in order to provide joint Nordic climate change initiatives with more political weight and an institutional basis (Nordisk Ministerråd, 2016a, pp. 12, 56-58).

The aim of functioning more flexibly implied that oneoff informal ministerial meetings could be convened and ad hoc ministerial councils could be established (Nordisk Ministerråd, 2016a, pp. 12-13, 58-62). Such ad hoc councils may, within a limited and specified period of time, deal with a specific field of cooperation not covered by the existing structures. This proposal was implemented soon when an ad hoc council for digitalization was inaugurated in $\mathbf{2 0 1 7}$ for three years. Digitalization is indeed another topical and important issue asking for political action, for example to enable the use of national electronic identification systems across the Nordic borders. The overarching aim of the new cooperation was to turn Norden into a digital frontrunner region (Nordisk Ministerråd, 2018). As a sign of the desired flexibility, even the Baltic countries were invited to participate in the ad hoc cooperation although not being members of the Nordic Council of Ministers. Initially, it also has been the intention to establish an ad hoc ministerial council for cooperation in the field of integration of refugees and immigrants, but related plans have been dropped due to disagreement among the governments. At least an informal ministerial meeting in autumn 2016 launched a cooperation programme on integration. The aim of this multi-sectoral programme was to coordinate and harmonise integration measures and to learn from each other by intensifying the dialogue and exchanging information among national agencies on the situation of immigrants and refugees in the respective countries (Nordisk Ministerråd, 2016b). However, its purpose and objectives only came into being on the basis of the lowest common denominator and remained unclear. In practice, the programme did not have much relevance and substance but appeared to have a mainly symbolic value. Closer cooperation on actual migration and asylum policies, including intra-Nordic distribution schemes and joint minimum criteria for accepting refugees as recommended by several left-wing delegates to the Nordic Council, has been deemed unthinkable by the governments.

Another important issue in the reform recommendations was a more prominent role for the heads of government in the formal cooperation, including greater policy-making powers (Nordisk Ministerråd, 2016a, pp. 14, 73-74) somewhat along the lines of the EU's European Council. Traditionally, prime ministers, foreign and defence ministers get regularly together in more informal settings outside the formal structures only. Therefore, the intension was to link both levels more closely and to involve the heads of government on a more systematic and regular basis in ongoing projects of the Nordic Council of Ministers in order to give the formal cooperation more political weight and visibility. Toward this end, instruments such as declarations and political initiatives by the prime ministers were recommended 
to be used more systematically and regularly. However, similar ambitions had been expressed various times in the past without sorting any visible effect. Also this time, it seems that not much has changed in practice.

Unlike the Nordic Council of Ministers, the Nordic Council has not initiated any far-reaching structural reforms since 2001. Its main focus has been on reviving the political debate and increasing the political relevance of parliamentary cooperation. This also implied discussing topical but politically sensitive issues of international interest and relevance outside the official agenda of institutionalized Nordic cooperation such as migration, border controls, EU-affairs and foreign and security policies. In this regard, the Nordic Council intends to play the role of initiator encouraging the intergovernmental level to take its initiatives up and to consider more formal cooperation in these fields (Opitz \& Etzold, 2018, p. 4). This has, however, only happened to a limited extent so far, taking into consideration that the Nordic Council's recommendations to the Nordic Council of Ministers are non-binding. To give the Nordic Council's recommendations more weight, it would be necessary to elevate the body in relation to the Nordic Council of Ministers and to link their activities and themes more closely.

The journey toward more political relevance had not ended here. In summer 2019, the Nordic Council of Ministers launched a new vision for Norden according to which it should become "the most sustainable and integrated region in the world by 2030" (Nordic Council of Ministers, 2019). The cooperation in the Nordic Council of Ministers must serve this purpose (Nordic Council of Ministers, 2019). To put this vision into practice, the future priorities of the cooperation within the Nordic Council of Ministers should be to turn the Nordic region into a green, competitive and socially sustainable Nordic Region. To succeed, it is necessary that all parts of the Nordic Council of Ministers' structures identify and formulate main goals linked to the vision as a basis for intersectoral action plans for the implementation of the strategic priorities including a clear allocation of responsibilities (Nordic Council of Ministers, 2019). As already outlined in the previous reform proposals, representatives of civil society as well as the business community were given a voice in this effort as well. In mid-2020, an action plan for the implementation of the vision had been drafted. All Nordic ministerial councils and other Nordic institutions contributed specific proposals within their area of expertise to the plan.

\section{New Relevance through Reforms? Strengths, Weaknesses and Potential of the Nordic Council of Ministers}

As outlined above, the Nordic Council of Ministers underwent an incremental transformation process including optimisation measures as well as several structural and budgetary reforms since the 1990s. The organisation showed a general willingness and ability to adapt to new external circumstances and to conduct several reforms, although slowly and reluctantly. In a previous study (Etzold, 2010), this and a number of other pre-conditions for continued existence and relevance of international organisations have been derived from theories of international relations, in this case neoliberal institutionalism and social-constructivism, as well as organisational theories and applied as independent variables to the case of the Nordic Council of Ministers and other regional organisations in Northern Europe. The Nordic Council of Ministers matched several of these theoretical criteria: A certain interest in the organisation by member states so long as it was of use for implementing their interests in combination with past achievements and the prospect for future success; maintaining old and creating new purposes; a strong anchoring of the idea and concept of Nordic cooperation in Nordic societies; common values and elements of a common identity as an ideological basis for the cooperation; the implementation of at least some changes and a well-developed and fairly influential bureaucracy with a secretary-general who owns some political weight and impact and is able to act as a driver for change.

Still, despite fulfilling these theoretical criteria and showing at least some adaptability in order to stay in existence and to retain some relevance, there has never been a major overhaul of structures and contents owing to considerable inertia within the Nordic Council of Ministers. There could indeed be situations in which big changes are not required to retain an international organisation's relevance. But once they appear necessary to keep an organisation going, displaying a principal willingness to change might not be enough, if it is not followed by tangible action. Overall, reforming the Nordic Council of Ministers has been perceived as difficult since despite all similarities the Nordic countries are in some political, economic and administrative respect different. In addition, views on certain reform measures and new fields of cooperation, in particular EU affairs, conflicted considerably. Owing to these differences, various measures including, for example, abolishing or restructuring certain ministerial councils or committees, received both approval as well as major criticism from stakeholders. It appeared that several stakeholders had fairly advanced ideas for change, while others were mainly interested in maintaining the status quo.

Therefore, several observers were critical of the reforms in the 1990s, their results and the organisation's significance: In their opinion the reforms have been insufficient and did not prevent the gradual marginalization of the Nordic Council of Ministers (Olesen \& Strang, 2016, p. 35). Also, the reforms undertaken during the 2000s were rather small-scale. Several of the various measures taken during these two periods have been similar, using the same key words such as 'more flexibility,' 'more effective,' 'increasing political relevance,' etc., without having any visible major effect. Therefore, some argued that to regain any political relevance in the future, the Nordic 
Council/the Nordic Council of Ministers system would require radical reform now (Olesen \& Strang, 2016, p. 40). This could imply "to make the Nordic Council of Ministers more ad hoc-oriented and flexible and to let it expand on mutual EU directive implementation and to secure a more coordinated Nordic voice in the EU" (Olesen \& Strang, 2016, p. 41).

Indeed, the Nordic Council of Ministers' most recent attempt to regain strength and impact, to act more flexibly, ad hoc and demand-oriented and to redefine its position within the wider landscape of cooperation in Europe has been politically more ambitious and widereaching than previous reform efforts, while again using similar reform language as before. As outlined above, it covered more institutional aspects, affecting all its structures including the ministerial councils, the secretariat and the highest political level, and has therefore been more comprehensive than previous reform efforts. The reform process also stretched over a longer period of time than previous ones and took, divided into two phases (see above), nearly four years.

While the reform process had officially concluded by late 2017, an evaluation was conducted in spring 2018 which included a survey among Nordic stakeholders. The overall conclusion was that the reforms have strengthened and improved the work of the Nordic Council of Ministers and that it therefore has taken an important step in the right direction (Resonans Kommunikation, 2018 , p. 5). There was a wide consensus that the reforms had laid the groundwork to sharpen the political and strategic focus, to allow the Secretariat to work more effectively and to render the cooperation more relevant and flexible (Resonans Kommunikation, 2018, pp. 63-64). The evaluation also revealed an awareness that the reforms were only the beginning of a longer process toward a more focussed and modern organisation which would require more time. Also both strengths and weaknesses of the process became obvious; it was widely seen as positive that the implementation was conducted quickly, the Secretary-General had played a decisive role and seemed to have managed to strengthen his overall role and position within the organisation and that important discussions about the added value and purpose of Nordic cooperation have been brought in motion. On the other hand, some criticized the fact that there was not enough space and time for an adequate involvement of all interested stakeholders and that the overall direction of the process had been unclear due to the very many recommendations and conclusions going in partly different directions. They wished for more communication and debate about the process and a clearer narrative including a common and tangible direction that all could have taken as a point of departure (Resonans Kommunikation, 2018, pp. 65-66).

The evaluation came perhaps too early and cannot be regarded as representative with only 56 respondents. Since most respondents were representatives of the structures of Nordic cooperation as well as national gov- ernments, there is also a certain bias at stake. Hardly any independent assessments on the most recent reform efforts exist thus far. Two years later, it is still difficult to judge for outsiders, whether the reform and modernisation process has been an overall success as several changes have not been communicated well and are therefore not very obvious. In several cases it is even difficult to identify whether and how they have actually been implemented (see for example the aforementioned case of the intended strengthened role of the prime ministers in official Nordic cooperation).

The effective implementation of reforms is complicated by a general problem the Nordic Council of Ministers and other structures of formal Nordic cooperation are facing: In recent years several differences in preferences and ways of handling various political issues among the five countries have become evident. In this context, an occasional lack in willingness to coordinate their policies and to cooperate within the established institutional structures by the governments has become apparent. These features potentially undermine the Nordic Council of Ministers' efforts to foster its relevance. As a case in point, the Nordic countries have not been able to find common answers to urging international challenges such as the changing security environment and migration. Additionally, the current Covid-19 pandemic has been handled rather differently in the various countries, driving a wedge between them rather than encouraging further cooperation, for example, in the health sector or in cross-border crisis management. Instead during the migration crisis 2015-2016, border controls had been reintroduced and in the Covid-19 crisis most intraNordic borders have even been completely closed. These events can be seen as major setbacks for the Nordic ambition of a borderless Norden after many years of work to abolish border obstacles. In both situations, a particular lack of communication among the governments as well as a tendency to return to more national approaches became apparent.

Against the backdrop of these and various other challenges in recent years, the weaknesses and limits of cooperation within the Nordic Council of Ministers have become evident: No majority voting or 'opting-out' system that would allow countries to abstain from a particular initiative while the remaining countries could move forward (Strang, 2012, p. 70) adding an extra flexibility; an overall lack in supra-national structures and policies; the Nordic Council of Ministers and Nordic cooperation in general seemed to have turned into a platform for projects and agencies for selling Norden as a trademark rather than a political arena for the dialogue and cooperation among various stakeholders (Strang, 2020); no common immigration and asylum policies; no common foreign and security policies, and lacking progress in establishing close cooperation and coordination in EU affairs. Reluctant efforts to establish more Nordic cooperation in these policy areas have at least resulted in more informal settings that however do not have an institu- 
tional backbone. This implies that the Nordic Council of Ministers has a limited role to play in those. For example, cooperation in defence policies takes place outside the Nordic Council of Ministers structures. Likewise, the Nordic Council of Ministers never evolved into an arena or an instrument for the coordination of EU policies and establishing a joint Nordic agenda on the European level (Olesen \& Strang, 2016, p. 36). Despite related ambitions, stronger EU cooperation remains difficult to put into practice owing to different interests and traditions even today. While the Nordic Council of Ministers Secretariat principally regards itself as a facilitator, as a meeting place and as an instrument which could be used to complement the member states' EU policies, in practice, it seems reluctant to take on a more proactive role. The old idea to establish a Nordic Council of Ministers representation in Brussels did not find any support among the governments at any point. These examples give proof of a certain dilemma that became apparent in any reform effort within the Nordic Council of Ministers in recent years. The interests of different stakeholders did not always match each other; some wanted to go further than others were willing to go. The consensus principle in decision taking in the Nordic Council of Ministers is an often-discussed case in point. Several stakeholders wanted to have it replaced by majority voting or an 'opting-out' system (see above) to render the organisation more flexible and responsive. Others argued against it since for them it is an important characteristic standing for the whole principle of Nordic cooperation: cooperation in fields where common interests exist and on which all can agree.

Thus, against the light of the not very favourable current pre-conditions, the real effect of the recent reform efforts in a long-term perspective and hence also the relevance of the Nordic Council of Ministers might partly depend on whether the Nordic countries will be able to find a new common understanding on what they want and are realistically able to achieve together. This applies to both the cooperation within the existing institutional framework as well as more informal settings, in case the organisation is not perceived as the suitable framework for dealing with certain issues. To make this work, a clear division of labour between both levels and a clear assignment of responsibilities to each of them would be helpful. The success of reforms also depends on mutual support and trust: Governments must transfer the necessary competences and resources to the Nordic Council of Ministers to achieve results while the institution has to convince the governments of its added value (Opitz \& Etzold, 2018, p. 8) in order not to be sidelined. The Nordic Council of Ministers is likely to be relevant to the Nordic countries and their governments when it is able to make a contribution to solving common problems and making the governments communicate and cooperate effectively and efficiently with each other in certain policy areas such as environment, climate, social affairs and research. To establish its relevance, it would help when there is clear evidence that important political decisions affecting Norden have been taken within a Nordic Council of Ministers setting, i.e., one of the ministerial councils. Indeed along the lines of Strang's (2020) aforementioned assessment, the Nordic Council of Ministers might find more political relevance when again being used more as a political arena and as a platform for facilitating the dialogue and the cooperation among various stakeholders, not just governments.

Furthermore, in order to the reforms to be effective the Nordic Council of Ministers would need to set clear realistic goals for itself based on an honest assessment of what the organisation is actually capable of. Visions such as the one of August 2019 can be useful to set ambitions and the general path for future cooperation and look attractive as a trademark and selling point. As an overall guideline they might be particularly helpful when they match the capacities and capabilities of an organisation to achieve such ambitious goals. Otherwise they might just cause disappointment. Owing to the current circumstances and challenges, it is at least questionable whether it is feasible and realistic for the Nordic Council of Ministers to turn the Nordic region into the "most integrated and sustainable region in the world" (Nordic Council of Ministers, 2019) and whether it is really necessary to be 'best.' The main goal might rather be to find common solutions to tangible common challenges through cooperation, matching the organisation's capabilities and strengths.

\section{Conclusions and Perspectives}

Despite obvious shortcomings and inertia, the Nordic Council of Ministers has at least undertaken several efforts to adapt to new external circumstances in the past and to retain some relevance and meaning for the Nordic countries' governments. The organisation is particularly able to achieve tangible results in those policy areas in which common interests exist such as environment, climate, research, removing border obstacles and social affairs. The most recent reform process has been ambitious, thus more ambitious than the previous ones, affecting various institutional aspects. It has sorted some positive effect in some areas, while in others clear results are not in place so far or not visible. The current difficult circumstances and challenges do not make any reform process an easy task.

Against the background of the Nordic Council of Ministers' strengths, weaknesses and shortcomings, Nordic cooperation as it is conducted within the Nordic Council of Ministers can most fittingly be characterized by differentiated integration rather than constituting a common political order of its own. Differentiated integration is currently widely discussed in academic circles against the light of the UK's exit from the EU (for example Gänzle, Leruth, \& Trondal, 2019). Along these lines, the Nordic Council of Ministers promotes full integration only to a limited degree but respects integra- 
tion to different extents and speeds by fostering cooperation and coordination of only certain policies where these are possible or desired and provide some further added value. It might indeed strengthen Nordic cooperation and the Nordic Council of Ministers in particular if the Nordic countries would be able to develop a strong common political voice in European and international affairs by establishing effective joint policies and if the Nordic Council of Ministers would be able to play a role in this. But this cannot be forced so long as a strong common political will and a strong common denominator do not exist. This creates a certain dilemma. But instead of cooperating on the basis of the lowest common denominator, the Nordic Council of Ministers might rather focus on a selected number of aforementioned areas in which close cooperation is politically most relevant, in which strong common interest exist, where an added value is given and where the Nordic countries and their citizens could profit most from the cooperation. By doing so, the Nordic Council of Ministers could still complement and contribute to efforts at the European/EU level trough joint action by building on its strengths and simultaneously being aware of its limits. Even without striving for deeper integration, the body could serve as a role model for cooperation among other groups of countries of one region, consisting of both EU member as well as non-member states. Both from an International as well as European Studies perspective, the Nordic Council of Ministers is also a good example of how international organisations despite difficulties at least attempt to adapt to new external circumstances and try to retain or even strengthen their relevance. Whether these attempts have been successful in the long run is a question for further research.

\section{Acknowledgments}

I am grateful to Politics and Governance to be given the chance to contribute an article on the Nordic Council of Ministers based on many years' research to this thematic issue on Nordic cooperation. I would like to thank the anonymous reviewers and the Academic Editors for useful comments in the review process. I also owe thanks to Professor Michael J. Geary at NTNU Trondheim for the valuable language editing.

\section{Conflict of Interests}

The author declares no conflict of interests.

\section{References}

Bagerstam, E. (1995). Nordiskt samarbete får vara onyttigt [Nordic cooperation might be useless]. Nordisk Kontakt, 6, 11-12.

Bennedsen, D. (1998). Tale 1 i forhandlingen om redegørelse $n r . R$ 5: Ministeren for nordisk samarbejdes redegørelse om det nordiske samarbejde
[Speech 1 in the negotation on statement No. R 5: The minister's for Nordic cooperation statement on Nordic cooperation]. Copenhagen: Folketinget.

Etzold, T. (2010). Live and let die: Adaptability and endurance of regional organisations in Northern Europe (Unpublished doctoral dissertation). Manchester Metropolitan University, Manchester, UK.

Gänzle, S., Leruth, B., \& Trondal, J. (Eds.). (2019). Differentiated Integration and disintegration in a post-Brexit era. London: Routledge.

Hagemann, H. (2005). Forelæsning om nordisk samarbejde for amerikanske gæster fredag den 25: Februar [Lecture on Nordic cooperation for American guests Friday 25 February]. Copenhagen: The Nordic Council Secretariat.

Hedegaard, C. (2005). Redegørelse af 6/10/2005 om det nordiske samarbejde [Statement on Nordic cooperation of 6/10/2005] (No. R 2). Copenhagen: Folketinget.

Jutila, K., \& Tikkala, T. (2009). Together or apart. Helsinki: Tankesmedjan e2.

Kristiansen, L.-A. (2001). Grenseløse begeistring [Unlimited enthusiasm]. Stat \& Styring, 5, 55-58.

Laursen, J. N., \& Olesen, T. B. (1998). A Nordic alternative to Europe (Core Working Paper). Copenhagen: Institute of Political Science.

Maertens, M. (1997). Norden in der EU: Jeder kämpft für sich allein [Norden in the EU: Everyone fights for himself]. Nordeuropaforum: Zeitschrift für Politik, Wirtschaft und Kultur, 1, 1-44.

Nordic Council, \& Nordic Council of Ministers. (2000). Open to the winds of change: Norden 2000 (Wise Men Report). Copenhagen: Nordic Council and Nordic Council of Ministers.

Nordic Council of Ministers. (2019). Our vision 2030: The Nordic region will become the most sustainable and integrated region in the world. Nordic Cooperation. Retrieved from https://www.norden.org/ en/declaration/our-vision-2030

Nordic Council of Ministers. (2020). About the Nordic Council of Ministers. Nordic Co-operation. Retrieved from https://www.norden.org/en/information/ about-nordic-council-ministers-secretariat

Nordiska Rådet. (1973). The role of the Nordic Countries in European cooperation (Conference Report). Stockholm: Nordisk Utredningsserie.

Nordisk Ministerråd. (1998). Plandokument och budget 1999 [Planning document and budget]. Copenhagen: Nordisk Ministerråd.

Nordisk Ministerråd. (2009). Norden i Fremdrift 2010: Det danske formandskabprogram for Nordisk ministerråd 2010 [Norden in progress 2010: The Danish chairmanship programme for the Nordic Council of Ministers 2010]. Copenhagen: Nordisk Ministerråd.

Nordisk Ministerråd. (2014a). Norden: Tillsammans är vi starkare [Norden: Together we are stronger]. Nordiskt samarbete. Retrieved from https://www. norden.org/sv/declaration/norden-tillsammans-arvi-starkare 
Nordisk Ministerråd. (2014b). Nyt Norden: Afrapportering på generalsekretærens moderniseringsopdrag [New Norden: Report on the secretary-general's modernisation task]. Copenhagen: Nordisk Ministerråd. Retrieved from http://norden.diva-portal.org/ smash/get/diva2:749241/FULLTEXT01.pdf

Nordisk Ministerråd. (2016a). Nordens tid er nu: Nyt Norden 2.0: naeste fase af reformarbejdet [Norden's time is now: New Norden 2.0: The next phase of the reform work]. Copenhagen: Nordisk Ministerråd. Retrieved from http://norden.diva-portal.org/ smash/get/diva2:967562/FULLTEXT02.pdf

Nordisk Ministerråd. (2016b). Strykelse af det nordiske samarbejde om inkludering av flygtninge og indvandrere [Strengthening of Nordic cooperation on the integration of refugees and immigrants]. Nordiskt samarbete. Retrieved from https://www.norden. org/no/news/fullt-trykk-pa-nordisk-

erfaringsutveksling

Nordisk Ministerråd. (2018). Reformerat samarbete skapar mer nordisk nytta [Reformed cooperation creates more Nordic value]. Nordiskt samarbete. Retrieved from https://www.norden.org/sv/news/reformeratsamarbete-skapar-mer-nordisk-nytta

Olesen, T. B., \& Strang, J. (2016). European challenge to Nordic institutional cooperation. In J. Strang (Ed.), Nordic cooperation: A European region in transition (pp. 27-47). Oxon: Routledge.

Olsen, J. P. (1998). Skiftende politiske fellesskap [Changing political partnership]. In J. P. Olsen \& B. O. Sverdrup (Eds.), Europa i Norden: Europeisering av nordisk samarbeid [Europe in Norden: Europeanisation of Nordic cooperation] (pp. 344-367). Oslo: Tano Aschehoug.

Opitz, C., \& Etzold, T. (2018). Seeking renewed relevance: Institutions of Nordic cooperation in the reform process (SWP Comment No. 3). Berlin: German Institute for International and Security Affairs.
Resonans Kommunikation. (2018). Evaluering af reformarbejdet Nyt Norden i Nordisk Ministerrad 2014-2017 [Evaluation of the reform works New Norden in the Nordic Council of Minsters 2014-2017]. Copenhagen: NORDEN. Retrieved from https://www.norden.org/sites/default/files/201808/Evaluering\%20af\%20Nyt\%20Norden\%2026-0418.pdf

Schumacher, T. (2000a). The emergence of the new Nordic co-operation (Working Paper No. 6). Copenhagen: Dansk Udenrigspolitisk Institut.

Schumacher, T. (2000b). Die nordische Allianz in der Europäischen Union [The Nordic alliance in the European Union]. Opladen: Leske + Budrich.

Stenbäck, P. (1997). Introductory remarks: The European Shift in Nordic Co-operation. In P. Stenbäck (Ed.), The Nordic countries and the new Europe (pp. 7-10). Copenhagen: Nordic Council of Ministers.

Strang, J. (2012). Nordiska Gemenskaper: En Vision för samarbetet [Nordic communities: A vision for cooperation]. Copenhagen: Nordiska Rådet.

Strang, J. (2020, June 26). Det nordiska samarbetet står handfallet inför kriser som drabbar hela regionen på en gång [Nordic cooperation is helpless in crises that threaten the whole region directly]. Huvudstabladet. Retrieved from https://www.hbl.fi/ artikel/det-nordiska-samarbetet-star-handfalletinfor-kriser-som-drabbar-hela-regionen-pa-engang/?fbclid=IwAR2uSyGs3JfuEk_TJtnqeQF2Jd8_ W_IN5Jh2hH9ICnEHr4OBdtCBwOP-6bU

Wendt, F. (1965). Nordiska Rådet: Riksdagarnas nordiska samarbete [The Nordic Council: The parliaments' Nordic cooperation]. Copenhagen: Föreningen Norden.

Wendt, F. (1981). Cooperation in the Nordic countries: Achievements and obstacles. Stockholm: Almqvist and Wiksell International.

\section{About the Author}

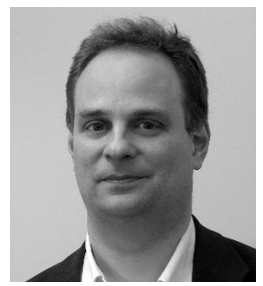

Tobias Etzold is a Lecturer in European Studies at the Norwegian University of Science and Technology in Trondheim since August 2020. Before, he worked as Research Associate and Head of the Research Centre Norden at the German Institute for International and Security Affairs in Berlin, in administration and as a Freelance Researcher. His research focuses on regional cooperation in Northern Europe, Nordic-German relations and Nordic-EU relations, foreign and domestic policies. 